\title{
Assessment of the effect of solid waste dump site on surrounding soil and river water quality in Teppi town, Southwest Ethiopia
}

Besufekad Asres Mekonnen ( $\nabla$ besusweet12@gmail.com )

Mizan-Tepi University https://orcid.org/0000-0003-4831-0027

Alemayehu Haddis

Jimma University College of Public Health and Medical Sciences

Wuhib Zeine

Jimma University College of Public Health and Medical Sciences

Research article

Keywords: Solid waste, Dumpsite, Leachate, Soil, Water

Posted Date: July 12th, 2019

DOI: https://doi.org/10.21203/rs.2.11274/v1

License: (c) (i) This work is licensed under a Creative Commons Attribution 4.0 International License.

Read Full License 


\section{Abstract}

Background An increase in the urban population and the rising demand for food and other essentials perpetuate a rise in the amount of waste being generated daily by each household. In low-income countries, this waste is eventually thrown into open dump sites. It can cause severe impacts on human health and the surrounding environment. This study was aimed at assessing the effect of a solid waste dump site of Teppi town on surrounding soil and river water quality. Methods A total of three surface water, one leachate water samples, and four soil samples were collected and were analyzed. Six heavy metals for surface water and leachate samples and four heavy metals for soil samples were measured by flame atomic absorption spectroscopy. Additionally, physical and chemical parameters were analyzed using standard methods. The soil and water data were analyzed statistically using Origin pro version 8.0 computer software packages. Analysis of variance (ANOVA) was used to assess whether the mean values of heavy metals and physicochemical parameters in soil and water samples varied significantly between distances and location from the dump site, possibilities less than $0.05(p<0.05)$ was considered statistically significant. Results $\mathrm{pH}$ of soil was slightly basic $(\mathrm{pH} 8 \pm 0.1$ up to $8.7 \pm 0.21$. Similarly, EC was lower in 60 meters $(1800 \pm 0.5 \mu \mathrm{s} / \mathrm{cm})$ and higher in the other sample sites $(3490 \pm 0.66-4920 \pm 1.04 \mu \mathrm{s} / \mathrm{cm})$. The concentration of heavy metals such as cadmium $(0.53 \pm 0.01-2.26 \pm 0.02 \mathrm{mg} / \mathrm{kg})$, zinc $(623.93 \pm 0.29$ $859.41 \pm 0.02 \mathrm{mg} / \mathrm{kg})$, lead $(3.26 \pm 0.25-57.560 .26 \mathrm{mg} / \mathrm{kg})$, and copper $(204.06 \pm 0.06337 .11 \pm 0.01 \mathrm{mg} / \mathrm{kg})$ in the sample soils has been found to be higher than Ethiopian EPA and USEPA guideline values. Lead, cadmium, manganese, nickel, copper, and zinc in the leachate water and nickel and manganese in nearby river water, total dissolved solid, BOD5, chemical oxygen demand, and turbidity for both leachate and stream water samples were found to be higher than the Ethiopian EPA and WHO standard guideline values. Conclusions The finding suggested that solid waste open dump site adversely affects soil and water quality in the study area and probable source of human health risks via the food chain. The soil in the area requires Phytoremediation technologies. In addition, sanitary landfill is recommended.

\section{Background}

Thousands of tons of solid wastes are generated daily in Africa (Asuma, 2013; Sankoh and Yan, 2013). Less than half of the solid waste produced is collected and 95 percent of that amount is either indiscriminately thrown away at various dumping sites on the periphery of urban centers or at a number of so-called temporary sites and typically empty lots scattered throughout the city (Regassa et al., 2011). The indiscriminate and open disposal of waste can cause environmental degradation through introducing different toxicants including heavy metals in the soil and water compartments (Beyene and Banerjee, 2011; Kebede et al., 2016).

Surface water contamination plays a significant role as a population stressor because human beings are dependent on water for their existence. Rainfall events may alternately dilute toxicity or increase it if the rate of transport increases the flow of contaminants to the surface water. Rivers and streams are sinks for municipal solid wastes. Wastes are most often discharged into the receiving water bodies with little or no regard to their assimilative capacities (Ejaz and Janjua, 2012). 
Open dumping of municipal solid waste is a common practice in Ethiopia and the problem of solid waste disposal is one of the major problems of the community and municipalities (Berhanu, 2014 and Gedefaw, 2015). Recent study shows that in most towns municipal solid wastes are disposed of in open spaces without discriminating major residential areas, roadsides, drainage areas, even rivers, river side's and forests.

It leads to the introduction of hazardous substances including heavy metals in water and soil ecology (Beyene and Banerjee, 2011; Hailemariam and Ajeme, 2014). However, there is a need of comprehensive and detail studies about the content of heavy metals and the physical and chemical properties of soil and surface water around solid waste disposal facilities in Ethiopia. There are suggestions for further studies on heavy metals content in the soil profiles and surface water closer to dump sites (Hailemariam and Ajeme, 2014 Kebede et al., 2016). These heavy metals are adversely affected soil ecology, ground, surface water quality, and ultimately harmful to the health of human being by food chain (Pires et al., 2011; Bartoli et al., 2012; Nazir et al., 2015 and Rastegari et al., 2017).

Similarly, Teppi town is characterized by rapid population growth caused by natural increase and migration. Such a rapid increase in population together with the rapid development of the town has produced increasing volumes of solid waste. Indiscriminate solid waste disposal is actually a menace and embarrassment to Teppi town. Furthermore, a considerable percentage of solid wastes generated in Teppi town are disposed of unapproved dump site and in waterways (drainage system) and in open site near to residential area which adversely affects environmental friendliness. In fact, solid waste poses various threats to public health and adversely affects soil and water especially when it is not appropriately disposed of (Agwu, 2012).

Due to high rainfall experienced in the study area, the dump site becomes washing out and the leachate with its pollutants draining into the Shay Wenz River. Fresh water is an imperative resource for people and provides many provisioning such as regulatory, cultural and ecosystem services for the community and the world in general (Troyer et al., 2016). Similarly, the river near to Teppi town solid waste dump site is largely used by the local communities for irrigation, bathing and drinking purpose. Therefore this paper aimed at assessing on improper disposal of solid waste and its pollution impacts on surrounding soil and water quality in Teppi town, southwest Ethiopia.

\section{Methods}

Study Area

Teppi is a town in southwest Ethiopia and well known by the production of coffee and spice. The town is located $621 \mathrm{~km}$ south of Addis Ababa. The town has a latitude and longitude of $7^{\circ} 12^{\prime} \mathrm{N} 35^{\circ} 27^{\prime} \mathrm{E}$ with a mean elevation of 1,097 meters above sea level (http://en.Wekipedia.org/wiki/Tepi. 10:44 July, 2019).

Study design and period 
Experimental study was used to characterize the leachate quality of solid waste dump site of Teppi town and to determine the quality of soil and surface water in the nearby dumpsite. The study was conducted from March to June 2017.

Samples collection and treatment

\section{Soil Samples Collection and Treatment}

The sample sites were selected by transects through simple random sampling method towards gully erosion based on US EPA (1992) soil sampling protocol. The sample points were being located at 10 meters, 30 meters, and 60 meters away from the periphery of dump site (Figure 1) (US EPA, 1992; Ideriah et. al., 2010; Bouzayani et al., 2014; Kebede et al., 2016). Soil samples were collected from the dump site by stainless steel hand augur (USDA, 1982; US EPA, 1992). Soil samples were taken at a depth of 0.5$20 \mathrm{~cm}$ from each sample point. The top $0.5 \mathrm{~cm}$ of surface soil was removed before the samples were taken (USDA, 1982; US EPA, 2002; Kebede et al., 2016). Meanwhile, the representative samples were coded and leveled on the information sheet and attached to the sample polyethylene bag. Then the collected samples were thoroughly mixed on the net polyethylene sheet and transported to the laboratory. Then air dried for 72 hours (US EPA, 2002; Kebede et al., 2016).

The soil samples were disaggregated with mortar and pestle finely powdered as well as thoroughly mixed together with other precautions to prevent contamination of the samples. Then air-dried soil sample were grinding, crushed and sieved through a $2 \mathrm{~mm}$ sieve and $<2 \mathrm{~mm}$ mesh size was used for analysis. The soil pH and electrical conductivity (US EPA, 2002; Raman and Narayanan, 2008; Beyene and Banerjee, 2011; Kebede et al., 2016), the total heavy metals and organic matter were detected with appropriate handling.

Water Samples Collection and Treatment

Water samples were taken through purposive random sampling techniques. Optimum amount of river water samples (1-liter) were collected from three different sample points upper stream from dump site (US) 100 meters far from the dump site, near to the dump site (DS1), and 100 meters far from the dump site in downstream direction( DS2) (Figure 1) (APHA, 1992; Hossain et al., 2014; Kumar et al., 2017).

These water samples were taken from the places where the river has laminar flow pattern in order to keep uniformity of samples and obtained at a depth of $10-15 \mathrm{~cm}$ below the surface water to avoid floating debris and put into 1-liter polyethylene bottles. The leachate sample $(L)$ was taken from the place near to dump site (APHA, 1992; Hossain et al., 2014; Kumar et al., 2017). At each sample points, two sets of water samples were collected into separate pre-cleaned 1-liter polyethylene bottles. $2.0 \mathrm{ml}$ of concentrated $\mathrm{HNO}_{3}$ was added to one of the bottles to bring the $\mathrm{pH}<2$ in order to prevent adsorptions of heavy metals on the bottom of sample containers. The acidified samples were used for elemental analysis and the non-acidified samples were used for biological analysis (APHA, 1992; Nartey et al., 2012; Hasan et al., 2016). 
Analytical Methods

Soil Samples Analysis

Soil electrical conductivity was analyzed by 1:2.5 soil-to-water extraction methods (USDA, 1982). The extract was measured by digital EC meter (H12300 EC/TDS/NaCl meter, HAWA instrument, Romania, model) and $\mathrm{pH}$ was measured with $\mathrm{pH}$ meter ( $\mathrm{pH}-016$ model) by using a glass electrode.

Determination of organic carbon in the soil was carried out through the spectrometric method of modified ISO 14235 (2015). Soil organic matter is oxidized under standard conditions with potassium dichromate (in excess) in sulfuric acid. The dichromate ions, which color the solution orange-red, were reduced to $\mathrm{Cr}^{3+}$ ions which color the solution green. A measured amount of potassium dichromate was used in excess of that needed to destroy the organic matter and the excess determined by titration with ferrous ammonium sulfate solution, using diphenylamine indicator to detect the first appearance of unoxidized ferrous ion. Assumed that the oxidation of one carbon atom of the organic matter produces four electrons, there is a direct relationship between the $\mathrm{Cr}^{3+}$ formed and the organic carbon 1.724 was used for conversion factor from \% OC to \% OM (Kuryntseva et al., 2016).

Heavy metals (lead, cadmium, copper, and zinc) extraction from soil samples were performed by an aqua regia digestion based on ISO 11466 recommended method (ISO, 1995). The air-dried sample was extracted with a hydrochloric/nitric acid 3:1 mixture by standing for 16 hours at room temperature, followed by boiling under reflux for 2 hours. The extract was then clarified and made up to volume 19 with nitric acid. The extract thus prepared was ready for the determination of elements by flame atomic absorption spectroscopy (PG 990, China model) (ISO, 1995; Sastre et al., 2002; Melaku et al., 2005).

Water Samples Analysis

In situ measurement of different parameters was held by using a digital portable multi-parameter probe (Micro 800 plain test, UK model). In addition, Electrical Conductivity (EC) and total dissolved solids (TDS) were measured by EC/TDS meter (Micro 800, Plain test, Wage tech company, UK, model) and turbidity was measured by turbidity meter (plain test, UK model).

At laboratory level, nitrate, sulfate, and fluoride were measured by the spectrometric method and the concentration was estimated by UV visible spectrophotometer (Plain test 7500, Wag Tech Company, UK model) (WHO, 2004; Osei et al., 2011; Nartey et al., 2012).

Some selected trace elements (copper, zinc, lead, cadmium, nickel, and manganese) were analyzed through in an unfiltered sample after vigorous digestion, or the sum of the concentrations of metals in the dissolved and suspended fractions. Note that total metals were defined operationally by the digestion procedure of APHA 3111c air/ acetylene oxidizing flame method (APHA, 1992) and the concentration of total elements was measured by flame atomic absorption spectroscopy (PG-990, China model). The dissolved oxygen content in the sample was measured by using azide modification of the titrimetric 
iodometric method (Section 4500-O.C). COD was determined by potassium dichromate in an open reflux method (APHA, 1999).

Data Analysis

The soil and water data were analyzed statistically using Origin pro version 8.0 computer software packages and Microsoft Excel. Analysis of variance (ANOVA) was used to assess whether the mean values of heavy metals and physicochemical parameters in soil and water samples varied significantly between distances and location from the dump site, possibilities less than $0.05(p<0.05)$ was considered statistically significant. The analyzed data was presented by using figures and tables. All the mean values were compared with heavy metals limits in soil and water prescribed by Ethiopian Environmental Protection Agency and US EPA standards.

\section{Results}

Soil pH, EC and organic Matter

The mean values of $\mathrm{pH}$ in the study area were between $8 \pm 0.1$ and $8.7 \pm 0.11$ slightly basic in nature. The sample points 10 meters, 30 meters and 60 meters far away from the dump site were found to be $8.7 \pm 0.11,8.4 \pm 0.1$ and $8.0 \pm 0.1$ respectively (slightly basic) and the means were significantly different at P-value $<0.05$ level. The conductivity of soil in the sample was recorded between $1800 \pm 0.5 \mu \mathrm{s} / \mathrm{cm}$ and $4920 \pm 1.04 \mu \mathrm{s} / \mathrm{cm}$. The sample site $60 \mathrm{~m}$ far from the dump site was measured the lowest value which shows $1800 \pm 0.5 \mu \mathrm{S} / \mathrm{cm}$ compared to the other sites which revealed $4920 \pm 1.04,3490 \pm 0.6 \mu \mathrm{S} / \mathrm{cm}$ respectively and at P-value $<0.05$ levels the means were significantly different. Organic matter was recorded $8.05 \%, 5.1 \%$ and $4.95 \%$ in 10 meters, 30 meters, and 60 meters respectively far from the dump site.

Heavy Metals Result of Soil Samples

The lowest $(3.26 \pm 0.25 \mathrm{mg} / \mathrm{kg})$ mean values of lead were recorded in 60 meters far from the dump site; in the contrary highest value was measured in 10 meters distance from the dump site $(57.56 \pm 0.26 \mathrm{mg} / \mathrm{kg})$. Moreover, the difference was statistically significant at $P$-value $<0.05$. Cadmium was one of the heavy metals analyzed in the dump site. It was found to be $2.26 \pm 0.21,1.6 \pm 0.01$ and $0.53 \pm 0.01 \mathrm{mg} / \mathrm{kg}$ in 10 meters, 30 meters, and 60 meters far from the periphery of dump site respectively. The means were significantly different at P-value $<0.05$ level.

Considering all samples obtained at the dump site copper ranged from the minimum found to be $204.06 \pm 0.05 \mathrm{mg} / \mathrm{kg}$ in the 60 meters far from the dump site. In the contrary highest mean values of copper were found in 10 meters and 30 meters far from the periphery of dump site shows $337.11 \pm 0.05$ and $286.11 \pm 0.2 \mathrm{mg} / \mathrm{kg}$ respectively and the means were significantly different at $P$-value $<0.05$ level. The highest mean values of zinc were found in 10 meters and 30 meters away from dump site which shows $859.41 \pm 0.2$ and $826.45 \pm 0.01 \mathrm{mg} / \mathrm{kg}$ respectively. The lowest mean concentration of zinc was revealed in 
60 meters away from the dump site $623.93 \pm 0.29 \mathrm{mg} / \mathrm{kg}$ and the means were significantly different at Pvalue $<0.05$ (Table 1$)$.

Physico-chemical parameters of the Surface Water and Leachate Samples

The mean values of temperature in the study area were revealed between

$22.00 \pm 0.1^{\circ} \mathrm{C}$ and $32.9 \pm 0.029^{\circ} \mathrm{C}$. The lowest water mean temperature was observed in the upper stream $\left(22.00 \pm 0.1^{\circ} \mathrm{C}\right)$. The mean values of $\mathrm{pH}$ in most of the water samples were slightly alkaline. The upper stream site was recorded the minimum $\mathrm{pH}$ value $(7.6 \pm 0.21)$ with the leachate sample site was showed the maximum mean value of $\mathrm{pH} 8.5 \pm 0.11$ and at $\mathrm{P}$-value $<0.05$ the means were significantly different.

Total dissolved solids indicate the salinity behavior of water. Water containing more than $500 \mathrm{mg} / \mathrm{l}$ of TDS is not considered desirable for domestic purpose and drinking water supplies WHO (2004). The mean value of TDS in the study area varied from $476.3 \pm 0.26 \mathrm{mg} / \mathrm{l}$ to $782.5 \pm 0.15 \mathrm{mg} / \mathrm{l}$; moreover, the means were significantly different at $p$-value $<0.05$ level. In most water turbidity is due to colloidal and extremely fine dispersions. The mean turbidity values were varied between $61.6 \pm 0.01$ and $798 \pm 0.5 \mathrm{NTU}$. The sample point of leachate was higher values of turbidity recorded $798 \pm 0.5 \mathrm{NTU}$. The other sites such as near to dump site and the downstream were measured $144 \pm 0.3$ and $135 \pm 0.7$ NTU respectively. The conductivity in water sample showed a high increment in leachate sample recorded $391.35 \pm 0.01$ and the minimum value of EC was measured in the upper stream which showed $238.2 \pm 0.2 \mu \mathrm{S} / \mathrm{cm}$ and the means were significantly different at $p$-value $<0.05$ level.

The BOD5 result for the water samples ranged from a minimum of $7.9 \mathrm{mg} / \mathrm{l}$ in the upper stream up to a maximum of $31 \mathrm{mg} / \mathrm{l}$ at near to dump site except for the leachate sample the highest BOD5 value was revealed $620 \mathrm{mg} / \mathrm{l}$. The results of COD in the study area were $10.51 \mathrm{mg} / \mathrm{l}, 935.3 \mathrm{mg} / \mathrm{l}, 61.33 \mathrm{mg} / \mathrm{l}$ and $18.4 \mathrm{mg} / \mathrm{l}$ in upper stream, leachate, near to dump site and downstream respectively. The amount of nitrate in the study area was measured between $0.8 \pm 0.01$ and $1.88 \pm 0.01 \mathrm{mg} / \mathrm{l}$. The finding were varied from the upper stream which recorded the lowest value compared to the other sample sites even if it was higher than the natural background level of $0.23 \mathrm{mg} / \mathrm{l}$. The remaining sample sites such as leachate, near to dump site and downstream were recorded $1.88 \pm 0.01,1.72 \pm 0.01$ and $1.48 \pm 0.01 \mathrm{mg} / \mathrm{l}$ respectively and at P-value $<0.05$ the means were significantly different. In the present analysis, fluoride concentration was found in all samples sites. The maximum concentration was found to be $1.71 \pm 0.01 \mathrm{mg} / \mathrm{ln}$ leachate sample and the minimum mean value was measured in the upper stream $(0.4 \pm 0.01 \mathrm{mg} / \mathrm{l})$ and the means were significantly different at $p$-value $<0.05$ level.

The mean values of sulfate in the study area were between $16 \pm 0.17 \mathrm{mg} / \mathrm{l}$ and $98 \pm 0.09 \mathrm{mg} / \mathrm{l}$. The highest mean value was registered in leachate and downstream sample sites $98 \pm 0.09$ and $63 \pm 0.5 \mathrm{mg} / \mathrm{l}$ respectively and the upper stream was recorded the lowest mean value $(16 \pm 0.2 \mathrm{mg} / \mathrm{l})$. In addition, at Pvalue $<0.05$ the means were significantly different. The mean value of potassium in leachate site was higher $(20 \pm 0.29 \mathrm{mg} / \mathrm{l})$, whereas the mean value of potassium in upper stream sample site was recorded $8.5 \pm 0.05 \pm \mathrm{mg} / \mathrm{l}$ lower than the sample sites near to dump site and downstream were revealed 
$12 . \pm 0.17 \mathrm{mg} / \mathrm{l}, 9.7 \pm 0.15 \mathrm{mg} / \mathrm{l}$ respectively and at P-value $<0.05$ the means were significantly different (Table 2 and Table 3).

Heavy Metal Result of Stream water and Leachate samples

The concentration of cadmium in all water samples were below detection limit $(<0.02 \mathrm{mg} / \mathrm{l})$ except for the leachate sample was recorded $0.3 \pm 0.01 \mathrm{mg} / \mathrm{l}$. A concentration of copper in water samples was found to be $0.26 \pm 0.9 \mathrm{mg} / \mathrm{l}, 0.02 \pm 0.95 \mathrm{mg} / \mathrm{l}$, and $0.018 \pm 1.04 \mathrm{mg} / \mathrm{l}$ in leachate, near to dump site, and downstream respectively and at $\mathrm{P}<0.05$ the means were significantly different.

The lowest concentration was revealed in the upper stream below the detection limit $(<0.018 \mathrm{mg} / \mathrm{l})$. A concentration of zinc in water samples were $0.21 \pm 0.2,0.54 \pm 0.2,0.39 \pm 0.18$, and $0.34 \pm 0.2 \mathrm{mg} / \mathrm{l}$ in upper stream, leachate, near to dump site, and downstream respectively and at $\mathrm{P}$-value $<0.05$ the means were significantly different.

The nickel concentration was high in most of the samples and its peak value was detected in the leachate sample $(0.4 \pm 0.13 \mathrm{mg} / \mathrm{l})$ and the lowest concentration of nickel was observed in the upper stream revealed below the detection limit $(<0.04 \mathrm{mg} / \mathrm{l})$ and at P-value $<0.05$ the means were significantly different. The mean values of lead were below the detection limit $(<0.08 \mathrm{mg} / \mathrm{l})$ in the upper stream, near to dump site and downstream sample sites. However, the leachate sample site was recorded $0.08 \pm 0.1 \mathrm{mg} / \mathrm{l}$. The mean values of manganese in the study area were $0.18 \pm 0.01 \mathrm{mg} / \mathrm{l}$ in the upper stream, $0.66 \pm 0.04$ $\mathrm{mg} / \mathrm{l}$ in leachate, $0.4 \pm 0.01 \mathrm{mg} / \mathrm{l}$ in near to dump site and $0.22 \pm 0.01 \mathrm{mg} / \mathrm{l}$ in downstream. However, the means were not significantly different at $p$-value $<0.05$ level (Table 3 and Table 4 ).

\section{Discussion}

Soil pH and EC

Soil pH in all sample sites was recorded slightly basic. Similar studies conduct in Addis Ababa, Accra (Ghana), Lagos (Nigeria), Maradi city (Niger Republic), and Adama (Ethiopia) solid waste disposal sites show slightly basic $\mathrm{pH}$ between 8.17 and 7.37 in the nearby dump sites. It might be due to soil with the high metallic burden (Beyene and Banerjee, 2011; Osei et al., 2011; Abdourahamane et al., 2015 and Kebede et al., 2016 ).

The EC values of soil at Teppi town solid waste dump site indicate the significant presence of trace metal ions or ionizable materials in the soil (Anapuwa and Precious, 2015). Therefore, the sample site 60 meters far from the dump site was recorded the lower EC values may show the low trace metal ions or ionizable materials present in the soil compared to the other sample site. However, the mean values of EC found in this study were less compared to another similar study at Addis Ababa dump site (Beyene and Banerjee, 2011) and the difference may be due to the composition of the waste and the soil condition.

Heavy Metals in Soil Samples 
The highest mean values of lead were observed in 10 meters and 30 meters far away from dump site recorded $57.56 \pm 0.26$ and $52.12 \pm 0.02 \mathrm{mg} / \mathrm{kg}$ respectively and the values were higher than the limit prescribed by Ethiopian EPA (2003) standard ( $40 \mathrm{mg} / \mathrm{kg}$ ). The movement of lead along the distance was favored by a slight nearest to the periphery of the dump site. It may be due to differences in soil pH and organic matter. According to Ashworth and Alloway (2008) and Shiva Kumar and Srikantaswamy (2014), it might be due to the presence of clay particle and organic matter. They are the major contributors towards sorbing of heavy metals. In addition, organic matter is important for the retention of metals by soil solids, thus decreasing mobility and bioavailability.

Ideriah et al. (2010) and Kebede et al. (2016) also substantiate this finding along the distance; however, the concentration was different compared to these study areas. This can be due to adsorption of lead on decomposed organic in sample sites near to dump site that restricts its mobility. In addition, it might be due to differences in the composition of the waste and the age of dump sites. However, the values of lead in this study area was lower compared to other studies done in Addis Ababa, India, and Maradi city (Niger Republic) dump sites which shows 17-852 mg/kg, 42.9-1833.5 mg/kg, and $79.133 \mathrm{mg} / \mathrm{kg}$ respectively (Beyene and Banerjee, 2011; Abdourahamane et al., 2015). It was higher than another study conducted by Kebede et al. (2016) in Adama city (Ethiopia) dump site which shows $1.033 \mathrm{mg} / \mathrm{kg}$. The difference may be due to the quantity and constitute of municipal solid waste that contains lead contents such as electronic waste, lead batteries, lead-based paints, pipes, plastics were indiscriminately dumped in the dump sites.

The values of cadmium also revealed in all along the distance in sample stations with the lowest value was measured in the 60 meters far from the dump site and the highest value was recorded in 10 meters distance from the dump site showed $2.26 \pm 0.21 \mathrm{mg} / \mathrm{kg}$. According to Haberhauer (2007), Ashworth and Alloway (2008), and Abu-Zahra et al. (2010) the highest concentrations with distance variation may be related with sorption of metals into the nature of soil with organic matter and $\mathrm{pH}$. Thus, it was expected to find different concentration in the 10 meters and 30 meters far away from the periphery of the dump site.

The values of cadmium in 10 meters, 30 meters, and 60 meters away from the dump site were higher than the limit prescribed by Ethiopian EPA (2003) standard $(0.5 \mathrm{mg} / \mathrm{kg})$. In addition, 10 meters and 30 meters away from the dump site were revealed higher values than the limit value prescribed by US EPA standard $(1.4 \mathrm{mg} / \mathrm{kg})$.

The finding was substantiated by other studies conducted in Adama and Addis Ababa solid waste dump sites reveal the higher average content of cadmium at nearest to the dump site (Beyene and Banerjee, 2011; Kebede et al., 2016). This indicated that solid waste open dump site contributes to increasing the concentration of heavy metals in the nearest soil. The finding in this study was higher than the findings of Abdourahamane et al. (2015) and Kebede et al. (2016) in Maradi (Niger Republic) and Adama (Ethiopia) dump sites respectively. 
However, The finding in this study was lower than another finding of Beyene and Banerjee (2011) in Addis Ababa dump site. The reason might be due to the difference in the age of dump sites and type of cadmium-containing wastes such as paints, batteries, plastics, agricultural use of sludge, fertilizers, galvanized materials, and cadmium plated containers were indiscriminately disposed of in the dump sites.

The values of copper in the study area was higher than the finding of Prechthai et al. (2008), Ideriah et al. (2010) and Beyene and Banerjee (2011). Moreover, the values were higher than the limit prescribed by US EPA standard of $200 \mathrm{mg} / \mathrm{kg}$ Haliru et al. (2014) except for the reference site. However, the values of copper in the study area were lower than the limit value prescribed by Ethiopian EPA (2003) standard of $500 \mathrm{mg} / \mathrm{kg}$.

The highest concentration of zinc with distance variation may be related with adsorption of metals into the nature of soil with organic matter, texture, and pH (Fern et al., 2007; Haberhauer, 2007; Abu-Zahra et al., 2010; Shiva Kumar and Srikantaswamy, 2014). The values of zinc in the study area was higher than the finding of Beyene and Banerjee (2011) and Abdourahamane et al, (2015) in Addis Ababa (Ethiopia) and Maradi city (Niger Republic) dump sites shows $131.8 \mathrm{mg} / \mathrm{kg}$ and $97.98 \mathrm{mg} / \mathrm{kg}$ respectively. It might be due to discharges of smelter slag, wastes, and the use of commercial products such as fertilizers and wood preservatives that contain zinc disposed of in the dump sites.

Zinc demonstrated considerable high mean values in the sample sites unless. It indicating that soil where largely polluted with zinc around the solid waste dump site. According to Haliru et al. (2014), it was revealed higher values than normal concentration in soil. Additionally, it was higher values than the limits prescribed by Ethiopian EPA, US EPA, EU and UK guideline values between 150 and $300 \mathrm{mg} / \mathrm{kg}$.

Physico-chemical and biological parameters of surface water and leachate samples

A study increase in water temperature in the course of leachate, downstream and the point near to dump sites were noticed i.e. $32.00 \pm 0.02^{\circ} \mathrm{C}, 27.00 \pm 0.2^{\circ} \mathrm{C}$, and $27.00 \pm 0.5^{\circ} \mathrm{C}$ respectively. A high in temperature was observed from leachate up to downstream. This might be due to differences in altitude and the presence of the effluents emanated from the open dump site. Since water temperature affects the concentration of biological, physical, and chemical constituents of water, the relatively high temperatures recorded would speed up the decomposition of organic matter in the water (Nartey et al., 2012).

The leachate sample was recorded higher $\mathrm{pH}(8.5 \pm 0.11)$. This shows that the leachate was alkaline and this was typical of the sample from aged wastes (Osei et al., 2011) and near to dump site and downstream sample sites recorded $8.1 \pm 0.11$ and $8 \pm 0.1$ respectively. The higher range of $\mathrm{pH}$ indicates higher productivity of water. Another studies conducted by Nkowacha et al. (2011), Karijia et al. (2013), Nirmala Dharmarathne (2013) and Hailemariam and Ajeme (2014) in Nigeria, Juba (South Sudan), Sri Lanka, and Addis Ababa (Ethiopia) solid waste dump sites respectively substantiate this finding which shows slightly basic $\mathrm{pH}$ in the nearby stream. However, the mean values of $\mathrm{pH}$ of water samples varied 
between $7.6 \pm 0.21$ and $8.5 \pm 0.1$ were found the limit value prescribed by World Health Organization (2004) between 6.5 and 8.5 and limit value prescribed by Ethiopia EPA (2003) between 6 and 9.

The mean value of TDS in sample point of the upper stream, leachate, near to dump site, and downstream from the dump sites were registered $446.3 \pm 0.26,782.5 \pm 0.15,557.9 \pm 0.1$, and $495.7 \pm 0.1 \mathrm{mg} / \mathrm{I}$ respectively. The sample points of leachate and near to dump sites were showed higher TDS values than the limit prescribed by WHO (2004) standard (500 mg/l). On the other hand sample point of the upper stream was lower values of TDS. This might be due to the effect of the dump site.

The lowest mean value of turbidity was observed in the upper stream sample site $61.6 \pm 0.01$ NTU even though it was above the limit prescribed by WHO (2004) standard value (25 NTU). It might be due to indiscriminate disposal of waste into the water bodies. The higher turbidity in the other sites might be due to the influence of open dump site. It was the highest turbidity values than investigated by Gopalkrushna (2011) in and around Akoyo city and Aljaradin and Persson (2012) in Jordan dump sites are reveal between 13.4 and 4.7 NTU and between 40 and 160 NTU respectively in the nearby stream and leachate water.

According to the US EPA (2002) turbidity values between 0.0 and 5.0 NTU show no visible turbidity, no

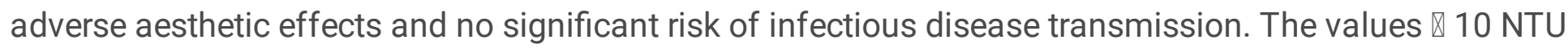
have severe aesthetic effects and the water carries an associated risk of diseases due to infectious agents and chemicals absorbed onto particulate matter (Nartey et al., 2012).

Electrical conductivity $(\mathrm{EC})$ is a measure of water capacity to convey electric current. It signifies the amount of total dissolved salts (Gopalkrushna, 2011) and it is also defined as a number of ions (positive and negative) offer in water (Hasan et al., 2016). The sample site of leachate, near to dump site, and downstream sample sites were recorded the maximum EC values than the upper stream. However, they fell under the EEPA (2003) and WHO (2004) acceptable limits of 1000 and $1400 \mu \mathrm{S} / \mathrm{cm}$ respectively.

High EC value was observed in leachate sample $391.35 \mu \mathrm{S} / \mathrm{cm}$. It indicating the presence of high amount of dissolved inorganic substances in ionized form in and around solid waste dump site (Siddiqui, 2015). In addition, the higher value of EC is a good indicator of the presence of contaminants such as potassium and sulfate (Nazir et al., 2015).

When considering the average value of conductivity in the leachate sample concluded that leachate was the high amount of ionizable material. The result of this study was less than the other studies conducted in Addis Ababa (Ethiopia) and Sri Lanka solid waste dump sites show $1102 \mu \mathrm{S} / \mathrm{cm}$ up to $3720 \mu \mathrm{S} / \mathrm{cm}$ and $1136 \mu \mathrm{S} / \mathrm{cm}$ respectively in the nearby stream (A.Abiye, 2012; Dharmarathne and Gunatilake, 2013). The result of this study was higher than a similar study conducted in Juba (South Sudan) the average values of electrical conductivity show between $89 \mu \mathrm{S} / \mathrm{cm}$ and $229 \mu \mathrm{S} / \mathrm{cm}$ in the nearby stream (Karijia et al., 2013). 
According to EU guidelines, the COD value in drinking water is $5 \mathrm{mg} / \mathrm{l}$ (Maqbool et al., 2011). It was observed that the values were higher than the permissible limit in all samples. It indicates the stream water was highly polluted with the chemicals which might have resulted from the solid waste dump site and indiscriminate disposal of solid waste in the nearby stream.

Nitrate values in all the sites were registered higher than the natural background level of $0.23 \mathrm{mg} / \mathrm{l}$. The presence of nitrate may be the result of waste being disposed of at the dump sites and indiscriminate disposal of solid waste into the water body. Thus, contamination of the water bodies with chemicals from the dump sites is likely to occur. It could be attributed to runoff from farms along the banks of the rivers which may contain organic fertilizers.

The values of nitrate in the study area were lower than the similar studies conducted in Addis Ababa (Ethiopia) and Accra (Ghana) solid waste dump sites show nitrate concentration between $2.0-2.2 \mathrm{mg} / \mathrm{l}$ and 4.18-30.8 mg/l respectively in the nearby stream (A. Abiye, 2012; Nartey et al. (2012) and higher than another study conducted at Accra (Ghana) nitrate concentration reveal $0.046 \mathrm{mg} / \mathrm{l}$ in the upper stream up to $0.418 \mathrm{mg} / \mathrm{l}$ in the downstream (Osei et al., 2011). However, the values revealed for all the sample sites did not exceed the limits prescribed by WHO (2004) and EEPA (2003) standards of $20 \mathrm{mg} / \mathrm{l}$ and $50 \mathrm{mg} / \mathrm{l}$ respectively.

Excess intake of fluoride through drinking water causes fluorosis on the human being (Gopalkrushna, 2011). All sample sites were recorded under the limit prescribed by EEPA (2003) $1 \mathrm{mg} / \mathrm{I}$ and WHO (2004) guideline value of $1.5 \mathrm{mg} / \mathrm{l}$ except for the leachate $(\mathrm{L})$ sample site the mean value was measured $1.71 \pm 0.01 \mathrm{mg} / \mathrm{l}$. However, the remaining site especially the point near to dump site (DS1) and the downstream sample location (DS2) registered the highest concentration compared with the upper stream $(0.8 \pm 0.01 \mathrm{mg} / \mathrm{l})$.

It was the highest result compared with Gopalkrushna (2011) finding lie less than $0.05 \mathrm{mg} / \mathrm{l}$ in the nearby stream. This might be due to fluoride-containing materials such as wood preservatives, glasses, and enamel indiscriminately dumps in an open dump site and in the nearby stream.

All mean values of sulfate were below the limits prescribed by EEPA (2003) and WHO (2004) standards $(200 \mathrm{mg} / \mathrm{l})$. The values were lower than other findings in Akot city and Addis Ababa solid waste dump sites the sulfate concentration varies between $263-62.8 \mathrm{mg} / \mathrm{l}$ and $53-342 \mathrm{mg} / \mathrm{l}$ respectively

(Gopalkrushna, 2011; A.Abiye, 2012) in the nearby stream but the values were higher than another finding in Accra (Ghana) dump site shows sulfate concentration varies b/n $0.2 \mathrm{mg} / \mathrm{l}$ in upper stream and 25 $\mathrm{mg} / \mathrm{l}$ in leachate water (Osei et al., 2011).

The potassium concentration in water samples was lower than $73 \mathrm{mg} / \mathrm{l}$ investigated by Kamboj et al., (2013) and potassium concentration in the study area was higher than $15 \mathrm{mg} / \mathrm{l}$ to $5.1 \mathrm{mg} / \mathrm{l}$ investigated by Gopalkrushna (2011). 
The values of $\mathrm{BOD}_{5}$ in the study area were higher than the limits prescribed by EEPA (2003) and WHO (2004) standards of $5 \mathrm{mg} / \mathrm{l}$. In addition, it was higher than a similar study conducted in Accra (Ghana) reveal $1.25 \mathrm{mg} / \mathrm{l}$ up to $100 \mathrm{mg} / \mathrm{l}$ in the nearby stream and leachate samples respectively (Osei et al., 2011). The high $\mathrm{BOD}_{5}$ values may be attributed to the discharge of organic waste into water bodies resulting in the uptake of DO in the oxidative breakdown of these wastes (Alemayehu, T., 2001). The dump site might be a factor promoting the loading of the water body with organic matter hence, the high $\mathrm{BOD}_{5}$ value.

Heavy Metals in River Water and Leachate Samples

Table 4 shows that the concentration of cadmium in all water samples were below detection limit $(<0.02 \mathrm{mg} / \mathrm{l})$ and below the limit prescribed by EEPA (2003) and WHO (2004) standards 0.005 and 0.003 $\mathrm{mg} / \mathrm{l}$ respectively except for leachate sample was revealed $0.3 \pm 0.01 \mathrm{mg} / \mathrm{l}$. It might be due to the solid waste composition that contained batteries and paints were indiscriminately disposed of in the dump site. It also might be due to the organic matter, $\mathrm{pH}$, and texture of soil (Haberhauer, 2007; Abu-Zahra et al., 2010; Shiva Kumar and Srikantaswamy, 2014) near to dump site which adsorbed the heavy metal and retained on it. Other studies in Accra (Ghana) and India confirm this finding (Raman and Narayanan, 2008; Osei et al., 2011 and Nartey et al., 2012) cadmium concentration in surface water near to the dump site shows lower than $0.003 \mathrm{mg} / \mathrm{l}$.

The concentration of copper in the study sites fell within this range except for the leachate sample showed the highest value of copper was revealed above the limit prescribed by EEPA (2003) and WHO (2004) standards $(0.1 \mathrm{mg} / \mathrm{l})$. It also higher value than similar studies conducted in Accra (Ghana) dump site reveal below $0.059 \mathrm{mg} / \mathrm{l}$ and lower than another finding in Sri Lanka the values of copper in surface and leachate water near to dump site reveal between 0.08 and $9.9 \mathrm{mg} / \mathrm{l}$ (Osei et al., 2011; Nirmala Dharmarathne, 2013 ). Hence, copper levels in the river systems pose no threat to the environment and human health.

The values of zinc in the study area were higher than another study conducted in Accra (Ghana) the concentration of zinc nearby stream is below detection limit (Nartey et al., 2012), however, lower than another finding in Sri Lanka record 0.1-9.9 mg/l in leachate water (Nirmala Dharmarathne, 2013). It might be due to discharges of smelter slag and wastes, and the use of commercial products such as fertilizers and wood preservatives that contain zinc disposed of in the water body and in the nearby dump site.

According to Maqbool et al., (2011) the permissible limit of zinc in water is $0.05 \mathrm{mg} / \mathrm{l}$ save for consumer. According to EEPA (2003), the prescribed limit of zinc in surface water lies between $0.003 \mathrm{mg} / \mathrm{l}$ and 0.5 $\mathrm{mg} / \mathrm{l}$. However, the values of zinc in the study area revealed between the limit prescribed by EEPA (2003) except for the leachate sample exceeded the standard.

According to $\mathrm{WHO}$ (2004), the standard value of a nickel is $0.02 \mathrm{mg} / \mathrm{l}$. Nickel values at the site near to dump site $(0.08 \mathrm{mg} / \mathrm{l})$ and the downstream locations $(0.06 \mathrm{mg} / \mathrm{l})$ were slightly greater than the permissible standard limit of WHO (2004) except for the upper stream the lowest concentration of nickel 
was observed below in detection limits $(<0.04 \mathrm{mg} / \mathrm{l})$. However, the values were lower than the limit prescribed by EEPA (2003) $0.1 \mathrm{mg} / \mathrm{l}$ except for the leachate sample. It might be due to indiscriminate disposal of nickel-containing solid wastes such as electroplating, zinc base casting and storage battery indiscriminately dump in open dump site near to the river. Another finding in Abbottabad (Pakistan) and Sri Lanka also authenticate this result nickel value ranges between 0.03 and $9.9 \mathrm{mg} / \mathrm{l}$ in the nearby stream and leachate water (Maqbool et al., 2011; Nirmala Dharmarathne, 2013).

The leachate water had the highest lead concentration compared to other streams. In addition, it contained high lead value than the permissible limits of EEPA (2003) and WHO (2004) standard (0.05 $\mathrm{mg} / \mathrm{l})$. It might be due to quantity and constitute of municipal solid waste that contains lead contents such as electronic waste, lead batteries, lead-based paints, pipes, and plastics were indiscriminately disposed of in the dump site. Gradually, due to erosion leachate might drain into the stream and increase lead concentration in stream water. Other studies in India and Accra (Ghana) dump sites authenticate this finding (Raman and Narayanan, 2008; Nartey et al., 2012) the lead values are revealed between below detection limit and $0.07 \mathrm{mg} / \mathrm{l}$ respectively in the nearby surface water.

The values of manganese at leachate and downstream sample sites were higher than the guideline values of EEPA (2003) $0.3 \mathrm{mg} / \mathrm{l}$ and WHO (2004) $0.1 \mathrm{mg} / \mathrm{l}$. The presence of manganese might be due to indiscriminate disposal of solid waste in the river and discharge from leachate. In addition, a high amount of manganese may be due to waste containing dry cell batteries, paints, glasses, and ceramics were disposed of in the open dump site and pollution from manganese dioxide cells for which the town has no controlled methods of disposal. The metal may also come from other sources such as domestic wastewater and sewage sludge disposal. Leachate and downstream sites registered the amount above prescribe limits of EEPA (2003) and WHO (2004) standards. However, the finding was lower than another finding of Nirmala Dharmarathne (2013) in Sri Lanka reveal $2.7 \mathrm{mg} / \mathrm{l}$ in leachate water near to dump site.

\section{Conclusions}

The $\mathrm{pH}$ of soil was higher (above 8 and basic) which indicates the influence of solid waste dumped in the area. Similarly, EC was lower in 60 meters and higher in 10 meters and 30 meters sample sites and the organic matter of the soil was decrease move towards form the dump site. The heavy metals such as cadmium, zinc, lead, and copper in soils has been found to be higher than EEPA (2003) and USEPA (1992) standards. The leachate sample was recorded higher concentration of heavy metals content such as lead, cadmium, manganese, nickel, copper, and adding increased concentrations of heavy metals such as manganese, nickel, copper, and zinc, to the adjacent river water especially near to dump site and downstream compared with the upper stream of the river from the dump site. The parameters exceeding the permissible limits of EEPA (2003) and WHO (2004) standards included pH, TDS, Turbidity, BOD ${ }_{5}, \mathrm{COD}$, manganese, and nickel. Consequently, the water of the stream has been polluted physically and chemically through the indiscriminate disposal of solid waste and discharge of leachate. 
The soil in the study area needs different remediation technologies like Phytoremediation. Construction of erosion preventive brim is recommended in order to control the discharge of leachate in to adjacent stream waters. Constructions of geo-synthetic layer should be needed to prevent percolation of leachate into the groundwater. The municipality should sensitize the population to reduce the quantity of waste produced through re-use and recycling of waste material. The municipality should construct sanitary landfill to replace the present nearly indiscriminate disposal of solid waste in the open land, so as to reduce its level of nuisance on its immediate environment.

\section{Abbreviations}

APHA American Public Health association

BDL Below detection limit

BOD Biological Oxygen Demand

$\mathrm{CH} 4 \quad$ Methane Gas

CO2 Carbon Dioxide

COD Chemical Oxygen Demand

DS1 Near to dump site

DS2 Downstream sample site

EC Electrical Conductivity

EEPA Ethiopian Environmental Protection Agency

EU European Union

FAAS Flame Atomic Absorption Spectroscopy

GHG Green House Gas

HNO3 Nitric Acid

$\mathrm{HCl} \quad$ Hydrochloric Acid

ISO International Standardization Organization

$\mathrm{KCl} \quad$ Potassium Chloride

$\mathrm{L} \quad$ Leachate sample site

$\mathrm{Mg} / \mathrm{L} \quad$ Mille Gram Per liter

$\mathrm{ml} \quad$ Mille liter

MPI Metal pollution Index

MSW Municipal Solid Waste

MSWM Municipal Solid Waste Management

NA- Not Available

$\mathrm{NaCl}$ Sodium Chloride

OC Organic Carbon

OM Organic Matter

PPm Parts per million

SNNPR Southern Nations Nationalities People's Region

SWM Solid Waste Management

Page $15 / 24$ 
TDS Total Dissolved Solid

USAID United State America International Development

USDA United State Department of Agriculture

US EPA United State of America Environmental Protection Authority

US Upper stream sample site

UK United Kingdom

UV Ultra Violate

WHO World Health Organization

\section{Declarations}

Ethical Consideration

Written consent was obtained from Jimma University, Institute of Health faculty of Public Health ethical review Committee about the study done in Teppi town solid waste dump site.

Availability of data and materials

All data generated or analyzed during this study are included in this published article.

Competing interests

The authors declare that they have no competing interests" in this section.

Funding

The Authors acknowledged Teppi city administration for their assistance in finance for field and experimental work and transport facility during data collection.

Authors' contributions

All authors' have read and approved the manuscript before submitted to the BMC Public Health journal.

BM: Proposal development, field work, experimental work, data analysis, result writing and manuscript preparation

$\mathrm{AH}$ and WZ: reviewing the proposal, data analysis and result writing

Acknowledgment

The Authors acknowledged Southwest Ethiopia soil research laboratory assistances, Teppi town water department laboratory technicians, JIJE analytical testing service laboratory assistants in Addis Ababa and Jimma university environmental health science and technology laboratory technicians for their wisely support. In addition, we would like to express our appreciation and thanks to Teppi town 
municipality workers of sanitation, beautification, and parks development department. Finally, we would like to gratefully acknowledge the help and encouragement of our families and friends.

\section{References}

A. Abiye, T. H. T. (2012) 'Environmental impact and vulnerability of the surface and ground water system from municipal solid waste disposal site': Environmental and Earth sciences, 67, pp. 71-80. doi: 10.1007/s12665- 011-1480-3.

Abu-Zahra, T. R. et al. (2010) 'Effect of organic matter sources on micronutrients and heavy metals accumulation in soil', Journal of Food, Agriculture and Environment, 8(3-4 part 2), pp. 1199-1202.

Adelekan, B. A. and Alawode, A. O. (2011) 'Contributions of municipal refuse dumps to heavy metals concentrations in soil profile and groundwater in Ibadan Nigeria', Journal of Applied Biosciences, 40, pp. 2727-2737.

Agwu, M. (2012) 'Issues and Challenges of Solid Waste Management Practices in Port-Harcourt City, Nigeriaa behavioural perspective', American Journal of Social and Management Sciences, 3(2), pp. 8392. doi: 10.5251/ajsms.2012.3.2.83.92.

Aljaradin, M. and Persson, K. M. (2012) 'Environmental impact of municipal solid waste landfills in semiarid climates -case study - Jordan', The Open Waste Management Journal, 5(1), pp. 28-39. doi: $10.2174 / 1876400201205010028$.

Alemayehu, T. (2001) 'The impact of uncontrolled waste disposal on surface watwer quality in Addis Ababa, Ethiopia', SINET: Ethiopian Journal Science, pp. 93-104. doi: 10.4314/sinet.v24i1.18177.

APHA (1992) 'APHA Method 3111: Standard methods for the examination of water and wastewater', pp. 3-18.

APHA (1999) 'Standard methods for the examination of water and wastewater part 4000', pp. 1-733.

Appel, C. and Ma, L. (2002) 'Concentration, pH, and surface charge effects on cadmium and lead sorption in three tropical soils', Journal of environmental quality, 31, pp. 581-589. doi: 10.2134/jeq2002.5810.

Ashworth, D. J. and Alloway, B. J. (2008) 'Influence of dissolved organic matter on the solubility of heavy metals in sewages sludge amended soils', communications in soil science and plant analysis, 39(3-4), pp. 538- 550. doi: 10.1080/00103620701826787.

Asuma, O. (2013) 'Leachate characterization and assessment of groundwater and surface water qualities near municipal solid waste dump site in Effurun , Delta State , Nigeria', Environmental and Earth sciences, 3(9), pp. 126-135.

Bartoli, G. et al. (2012) 'Heavy metal content in sediments along the Calore river : Relationships with physical chemical characteristics', Journal of Environmental Management. Elsevier Ltd, 95, pp. S9-S14. 
Doi: 10.1016/j.jenvman.2011.02.013.

Beyene, H. and Banerjee, S. (2011) 'Assessment of the Pollution Status of the Solid Waste Disposal Site of Addis Ababa City with Some Selected Trace Elements, Ethiopia', World Applied Sciences Journal, 14(7), pp. 1048-1057.

Birhanu, Y. and Berisa, G. (2015) 'Assessment of Solid Waste Management Practices and the Role of Public Participation in Jigjiga Town, Somali Regional State, Ethiopia', International Journal of Environmental protection and agency, 3(5), pp. 153-168.

Bouzayani, F., Aydi, A. and Abichou, T. (2014) 'Soil contamination by heavy metals in landfills : measurements from an unlined leachate storage basin', Springer International Publishing Switzerland, 4(March 2014), p. 186. doi: 10.1007/s10661-014-3757-y.

Duruibe, J. O., Ogwuegbu, M. O. C. and Egwurugwu, J. N. (2007) 'Heavy metal pollution and human biotoxiceffects', International journal of physical science, 2(5), pp. 112-118.

Ejaz, N. and Janjua, N. S. (2012) 'Solid waste management issues in small towns of developing world : a case study of Taxila City', International journal of environmental science and development, 3(2), pp. 167171.

Ethiopian Environmental Protection Authority (EEPA) and The United Nations Industrial Development Organization (2003) 'Guideline ambient environment standards for Ethiopia', pp. 1-103.

Fern, E., Vega, F. A. and Andrade, M. L. (2007) 'Heavy metal sorption and desorption capacity of soils containing endogenous contaminants', Journal of Hazardous Materials, 143, pp. 419-430. doi:

10.1016/j.jhazmat.2006.09.047.

Gedefaw, M. (2015) 'Assessing the Current Status of Solid Waste Management of Gondar Town, Ethiopia', scientific \& technology research, 4(9), pp. 28-36.

Haberhauer, G. J. L. M. H. G. G. (2007) 'Sorption of heavy metals on organic and inorganic soil constituents', Journal of Environmental Chemistry, 5, pp. 23-27. doi: 10.1007/s10311-006-0059-9.

Hailemariam, M. and Ajeme, A. (2014) 'Solid Waste Management in Adama, Ethiopia : Aspects and Challenges', International Journal of Environmental, Chemical, Ecological, Geological and Geophysical Engineering, 8(9), pp. 670-676.

Haliru, A., Ling, L. and Selaman, O. S. (2014) 'Environmental Burden of Heavy Metal Contamination Levels in Soil from Sewage Irrigation Area of Geriyo Catchment, Nigeria', Civil and Environmental research, 6(10), pp. 118-125.

Hasan, M. R. et al. (2016) 'Heavy metals distribution and contamination in surface water of the Bay of Bengal coast', cogent environmental science. cogent, 31(1), pp. 1-12. doi: 
Hossain Mdlokman, Das, Satyajit, H. M. K. (2014) 'Impact of land fill leachate on surface and ground water.' Journal of Environmental Science and Technology, pp. 337-346.

H, M. G. (2011) 'Determination of physico-chemical parameters of surface water samples in and around akot city', Research in chemistry and environment, 1(2), pp. 183-187.

Http: //en.Wekipedia.org/wiki/Tepi. 10:44 July, 2019.

Ideriah , T J K ; A Harry , F O ; Stanley , H O ; A Igbara, J. K. (2010) 'Heavy metal contamination of soils and vegetation around solid waste dumps in Port', Journal of Applied Science and Environmental Management, 14(1), pp. 101-109.

ISO (1995) 'Soil quality - Extraction of trace elements soluble in aqua regia'.

Kebede, A. A., Olani, D. D. and Edesa, T. G. (2016) 'Heavy metal content and physico chemical properties of soil around solid waste disposal sites', American Journal of scientific and Industrial research, 7(5), pp. 129-139. doi: 10.5251/ajsir.2016.7.5.129.136.

Karijia, M. K., Shihua, Q. and Lukaw, S. Y. (2013) 'The impact of poor municipal solid waste management practices and sanitation status on water quality and public health in cities of the least developed countries : the case of Juba, South Sudan', International Journal of Applied Science and Technology, 3(4), pp. 87-99.

Kumar, M. et al. (2017) 'Assessment of heavy metal concentrations in surface water sources in an industrial region of central India', Karbala International Journal of Modern Science. Elsevier Ltd, 1(1), pp. 9-14. doi: 10.1016/j.kijoms.2015.08.001.

Kuryntseva, P., Galitskaya, P. and Selivanovskaya, S. (2016) 'Changes in the ecological properties of organic wastes during their biological treatment', Waste Management. Elsevier Ltd, 58, pp. 90-97. doi: 10.1016/j.wasman.2016.09.031.

Maqbool, F ; Bhatti, Z ; Malik, Ah ; Pervez, A ; Mahmood, Q. (2011) 'Effect of Landfill Leachate on the Stream water Quality', International Journal of Environmental Research, 5(2), pp. 491-500.

Melaku, S., Dams, R. and Moens, L. (2005) 'Determination of trace elements in agricultural soil samples byinductively coupled plasma-mass spectrometry : Microwave acid digestion versus aqua regia extraction',journal of Analytical Chemistry Acta, 543, pp. 117-123. doi: 10.1016/j.aca.2005.04.055.

Nartey, V. K., Hayford, E. K. and Ametsi, S. K. (2012) 'Assessment of the Impact of Solid Waste Dumpsites on Some Surface Water Systems in the Accra Metropolitan Area, Ghana', Journal of Water Resource and Protection, 4(August), pp. 605-615. doi: 10.4236/jwarp.2012.48070. 
Nazir, R. et al. (2015) 'Accumulation of Heavy Metals ( $\mathrm{Ni}, \mathrm{Cu}, \mathrm{Cd}, \mathrm{Cr}, \mathrm{Pb}, \mathrm{Zn}, \mathrm{Fe}$ ) in the soil , water and plants and analysis of physico-chemical parameters of soil and water Collected from Tanda Dam kohat .', Pharmaceutical science and Research, 7(3), pp. 89-97.

Nirmala Dharmarathne, J. G. (2013) 'Leachate characterization and surface groundwater', International Journal of Scientific Research, 3(11), pp. 1-7.

Nkowacha, E. E., Pat-Mbano, E. C. and Nnaji, A. O. (2011) 'Effect of solid waste dump on river water quality: a paradigm in a Nigeria tropical environment', International journal for Science and Nature, 2(3), pp. 501-507.

Osei, J., Fianko, J. R. and Ganyaglo, S. Y. (2011) 'The impact of oblogo landfill site in Accra- Ghana on the surrounding environment', Environmental and earth sciences, 3(6), pp. 633-639.

Pastor, J. and Hernández, A. J. (2012) 'Heavy metals, salts and organic residues in old solid urban waste land fi lls and surface waters in their discharge areas : Determinants for restoring their impact', journal of environmental management. Elsevier Ltd, 95, pp. S42-S49. doi: 10.1016/j.jenvman.2011.06.048.

Pires, A., Martinho, G. and Chang, N. (2011) 'Solid waste management in European countries : A review of systems analysis techniques', Journal of Environmental Management. Elsevier Ltd, 92(4), pp. 10331050. doi: 10.1016/j.jenvman.2010.11.024.

Prechthai, T., Parkpian, P. and Visvanathan, C. (2008) 'Assessment of heavy metal contamination and its mobilization from municipal solid waste open dumping site', Journal of Hazardous Materials, 156, pp. 86-94.doi: 10.1016/j.jhazmat.2007.11.119.

Raman, N. and Narayanan, D. S. (2008) 'Impact of Solid Waste Effect on Ground Water and Soil Quality nearer to Pallavaram Solid Waste Landfill Site in Chennai', Rasayan Journal of Chemistry, 1(4), pp. 828836.

Rastegari, M. et al. (2017) 'Journal of African Earth Sciences Distribution, source identification and health risk assessment of soil heavy metals in urban areas of Isfahan province, Iran', Africa earth science, 132, pp. 16-26. Doi: 10.1016/j.jafrearsci.2017.04.026.

Salamatou I. Abdourahamane, Laminou O. Manzo, Tahirou I. Djima, Abdoul-Aziz M. Beido, Sani I. Saidou, Boubacar M. Moussa, A. M. and M. S. (2015) Impact of Solid Waste Disposal System on Soil in Maradi City (Niger Republic): A preliminary study of heavy metal contamination', International journal of current microbiology and applied sciences, 4(5), pp. 650-659.

Sankoh, F. P. and Yan, X. (2013) 'Problems of solid waste management in developing urban cities : a case study of Freetown, Sierra Leone', American Journal of Environmental Protection 2013; 2(5), pp. 113-120. Doi: 10.11648/j.ajep.20130205.11. 
Siddiqui, Y. S. (2015) 'Municipal Solid Waste Dumping Practice and Its impact', European International Journal of Science and Technology, 4(3), pp. 33-53.

Shiva Kumar, D. and Srikantaswamy, S. (2014) 'Factors Affecting on Mobility of Heavy Metals in Soil Environment', International Journal for Scientific Research \& Development, 2(3), pp. 201-203.

Troyer, N. De et al. (2016) 'Water Quality Assessment of Streams and Wetlands in a Fast Growing East African City', pp. 1-21. Doi: 10.3390/w8040123.

United State Environmental protection Agency, U. E. (1992) 'EPA Preparation of Soil Sampling Protocols : Sampling Techniques and Strategies', Office of research and development, 128 (July), pp. 1-17.

United State Environmental protection Agency (1992) Guidelines values for soil quality. USAID (2009) 'Solid waste : generation, handling, treatment and disposal', Forum the American People, (11).

USDA (1982) 'Soil Survey Laboratory Methods and procedures for collecting Soil Samples.' USDA Soil Conservation service, 1. Doi: 10.1111/j.1461-0248.2007.01139.x.

Wuana, R. A. and Okieimen, F. E. (2011) 'Heavy Metals in Contaminated Soils : A Review of Sources, Chemistry, Risks and Best Available Strategies for Remediation', International science Research Network, 2011, p. 20. doi: $10.5402 / 2011 / 402647$.

WHO (2004) guidelines for drinking water quality. $3^{\text {rd }}$ edition, edited by World health organization. Geneva: WHO library cataloguing.

\section{Tables}

Table 1: Concentration of $\mathrm{Pb}, \mathrm{Cu}, \mathrm{Cd}$ and $\mathrm{Zn}$ in soil around Teppi town sold waste dump site along different sample sites.

\begin{tabular}{|c|c|c|c|c|c|c|}
\hline $\begin{array}{ll}\text { Soil sample } \\
\text { site }\end{array}$ & $\mathrm{pH}$ & $\mathrm{EC}(\mu \mathrm{S} / \mathrm{cm})$ & $\operatorname{Lead}(\mathrm{mg} / \mathrm{kg})$ & $\begin{array}{l}\text { Copper } \\
(\mathrm{mg} / \mathrm{kg})\end{array}$ & $\begin{array}{ll} & \text { Cadmium } \\
(\mathrm{Mg} / \mathrm{kg}) & \end{array}$ & $\operatorname{Zinc}(\mathrm{Mg} / \mathrm{kg})$ \\
\hline $10 \mathrm{~m}$ & $8.7 \pm 0.21$ & $4920 \pm 1.04$ & $57.56 \pm 0.26$ & $286.11 \pm 0.2$ & $2.26 \pm 0.02$ & $859.41 \pm 0.02$ \\
\hline $30 \mathrm{~m}$ & $8.4 \pm 0.1$ & $3490 \pm 0.66$ & $52.21 \pm 0.02$ & $204.06 \pm 0.06$ & $1.6 \pm 0.01$ & $623.93 \pm 0.29$ \\
\hline $60 \mathrm{~m}$ & $8 \pm 0.1$ & $1800 \pm 0.5$ & $3.26 \pm 0.25$ & $337.11 \pm 0.01$ & $0.53 \pm 0.01$ & $826.45 \pm 0.01$ \\
\hline $\begin{array}{l}\text { US/EPA } \\
(1992)\end{array}$ & $6.5-8.5$ & 1400 & $50-100$ & $150-200$ & 1.4 & 300 \\
\hline Standard & & & & & & \\
\hline $\begin{array}{l}\text { EEPA } \\
(2003) \\
\text { standard }\end{array}$ & $6.5-9$ & 1000 & 40 & 500 & 0.5 & 500 \\
\hline
\end{tabular}


Physico-chemical parameters results of the Surface Water Samples Table 2:

\begin{tabular}{llllll}
\hline parameters & US & DS1 & DS2 & EEPA (2003) Standard & WHO (2004) Standard \\
\hline Temperature $\left(\mathrm{C}^{\circ}\right)$ & $22 \pm 0.1$ & $27.5 \pm 0.2$ & $27 \pm 0.5$ & $5-30$ & NA \\
pH & $7.6 \pm 0.21$ & $8.1 \pm 0.12$ & $8.0 \pm 0.1$ & $6-9$ & $6.5-8.5$ \\
EC $(\mu \mathrm{S} / \mathrm{cm})$ & $238.2 \pm 0.2$ & $281.3 \pm 0.01$ & $247.8 \pm 0.02$ & 1000 & 1400 \\
TDS $(\mathrm{mg} / \mathrm{l})$ & $446.3 \pm 0.2$ & $557.9 \pm 0.1$ & $495.7 \pm 0.1$ & $\mathrm{NA}$ & 500 \\
Turbidity $(\mathrm{NTU})$ & $61.6 \pm 0.01$ & $144.0 \pm 0.3$ & $135.3 \pm 0.7$ & $\mathrm{NA}$ & 25 \\
Nitrate $(\mathrm{mg} / \mathrm{l})$ & $0.8 \pm 0.01$ & $1.72 \pm 0.01$ & $1.48 \pm 0.01$ & 50 & 30 \\
Sulfate $(\mathrm{mg} / \mathrm{l})$ & $16 \pm 0.1$ & $26 \pm 0.8$ & $63 \pm 0.5$ & 200 & 200 \\
Potassium $(\mathrm{mg} / \mathrm{l})$ & $8.5 \pm 0.05$ & $12.1 \pm 0.17$ & $9.8 \pm 0.15$ & $\mathrm{NA}$ & 12 \\
Fluoride $(\mathrm{mg} / \mathrm{l})$ & $0.40 \pm 0.01$ & $0.88 \pm 0.01$ & $0.8 \pm 0.01$ & 1 & 1.5 \\
BOD $(\mathrm{mg} / \mathrm{l})$ & 7.9 & 31 & 12 & $<5$ & $<5$ \\
COD $(\mathrm{mg} / \mathrm{l})$ & 10.51 & 61.33 & 18.4 & 5 & $<5$ \\
\hline
\end{tabular}

The physico-chemical properties of stream water samples at Teppi town solid dump site along different sample location and guideline values.

Physico-chemical parameters results of the Leachate Sample Table 3:

The physico-chemical properties of leachate sample at Teppi town solid dump site along different sample location and guideline values.

\begin{tabular}{llll}
\hline parameters & $\begin{array}{l}\text { Leachate } \\
\text { sample }\end{array}$ & EEPA (2003) Standard & WHO (2004) Standard \\
\hline Temperature $\left(\mathrm{C}^{\circ}\right)$ & $32.9 \pm 0.29$ & $5-30$ & NA \\
pH & $8.5 \pm 0.12$ & $6-9$ & $6.5-8.5$ \\
EC $(\mu \mathrm{S} / \mathrm{cm})$ & $391.3 \pm 0.01$ & 1000 & 1400 \\
TDS $(\mathrm{mg} / \mathrm{l})$ & $782.5 \pm 0.15$ & $\mathrm{NA}$ & 500 \\
Turbidity $(\mathrm{NTU})$ & $798.4 \pm 0.5$ & $\mathrm{NA}$ & 25 \\
Nitrate $(\mathrm{mg} / \mathrm{l})$ & $1.88 \pm 0.01$ & 50 & 30 \\
Sulfate $(\mathrm{mg} / \mathrm{l})$ & $98 \pm 0.09$ & 200 & 200 \\
Potassium $(\mathrm{mg} / \mathrm{l})$ & $20.1 \pm 0.29$ & $\mathrm{NA}$ & 12 \\
Fluoride $(\mathrm{mg} / \mathrm{l})$ & $1.71 \pm 0.01$ & 1 & 1.5 \\
BOD $(\mathrm{mg} / \mathrm{l})$ & 620.2 & $<5$ & $<5$ \\
COD $(\mathrm{mg} / \mathrm{l})$ & 935.33 & 5 & $<5$ \\
\hline
\end{tabular}




\begin{tabular}{llllll}
\hline Parameters & US & DS1 & DS2 & EEPA (2003) Standard & WHO (2004) Standard \\
\hline Cadmium (mg/l) & Bdl & Bdl & Bdl & 0.005 & 0.003 \\
& & & & \\
Copper (mg/l) & Bdl & $0.02 \pm 0.95$ & $0.018 \pm 1.04$ & $0.05-1.1$ & 2 \\
Lead (mg/l) & Bdl & Bdl & Bdl & 0.1 & 0.05 \\
Zinc (mg/l) & $0.211 \pm 0.2$ & $0.39 \pm 0.18$ & $0.34 \pm 0.2$ & 0.5 & 0.05 \\
Nickel (mg/l) & Bdl & $0.08 \pm 0.1$ & $0.06 \pm 0.13$ & 0.1 & 0.02 \\
Manganese (mg/l) & $0.18 \pm 0.01$ & $0.4 \pm 0.1$ & $0.22 \pm 0.1$ & 0.3 & 0.1 \\
\hline
\end{tabular}

Table 4. Heavy Metal Result of Stream water samples

\begin{tabular}{llllll}
\hline Parameters & US & DS1 & DS2 & EEPA (2003) Standard & WHO (2004) Standard \\
\hline Cadmium (mg/l) & Bdl & Bdl & Bdl & 0.005 & 0.003 \\
& & & & \\
Copper (mg/l) & Bdl & $0.02 \pm 0.95$ & $0.018 \pm 1.04$ & $0.05-1.1$ & 2 \\
Lead (mg/l) & Bdl & Bdl & Bdl & 0.1 & 0.05 \\
Zinc (mg/l) & $0.211 \pm 0.2$ & $0.39 \pm 0.18$ & $0.34 \pm 0.2$ & 0.5 & 0.05 \\
Nickel (mg/l) & Bdl & $0.08 \pm 0.1$ & $0.06 \pm 0.13$ & 0.1 & 0.02 \\
Manganese (mg/l) & $0.18 \pm 0.01$ & $0.4 \pm 0.1$ & $0.22 \pm 0.1$ & 0.3 & 0.1 \\
\hline
\end{tabular}

Table 5. Heavy Metal Result of the Leachate sample

\begin{tabular}{llll}
\hline Parameters & Leachate & EEPA (2003) Standard & WHO (2004) Standard \\
\hline Cadmium (mg/l) & $0.3 \pm 0.01$ & 0.005 & 0.003 \\
& & & \\
& & & 2 \\
Copper (mg/l) & $0.26 \pm 1.084$ & $0.05-1.1$ & 0.05 \\
Lead (mg/l) & $0.08 \pm 0.1$ & 0.1 & 0.05 \\
Zinc (mg/l) & $0.54 \pm 0.2$ & 0.5 & 0.02 \\
Nickel (mg/l) & $0.4 \pm 0.1$ & 0.1 & 0.1 \\
Manganese (mg/l) & $0.66 \pm 0.04$ & 0.3 & \\
\hline
\end{tabular}


Figures

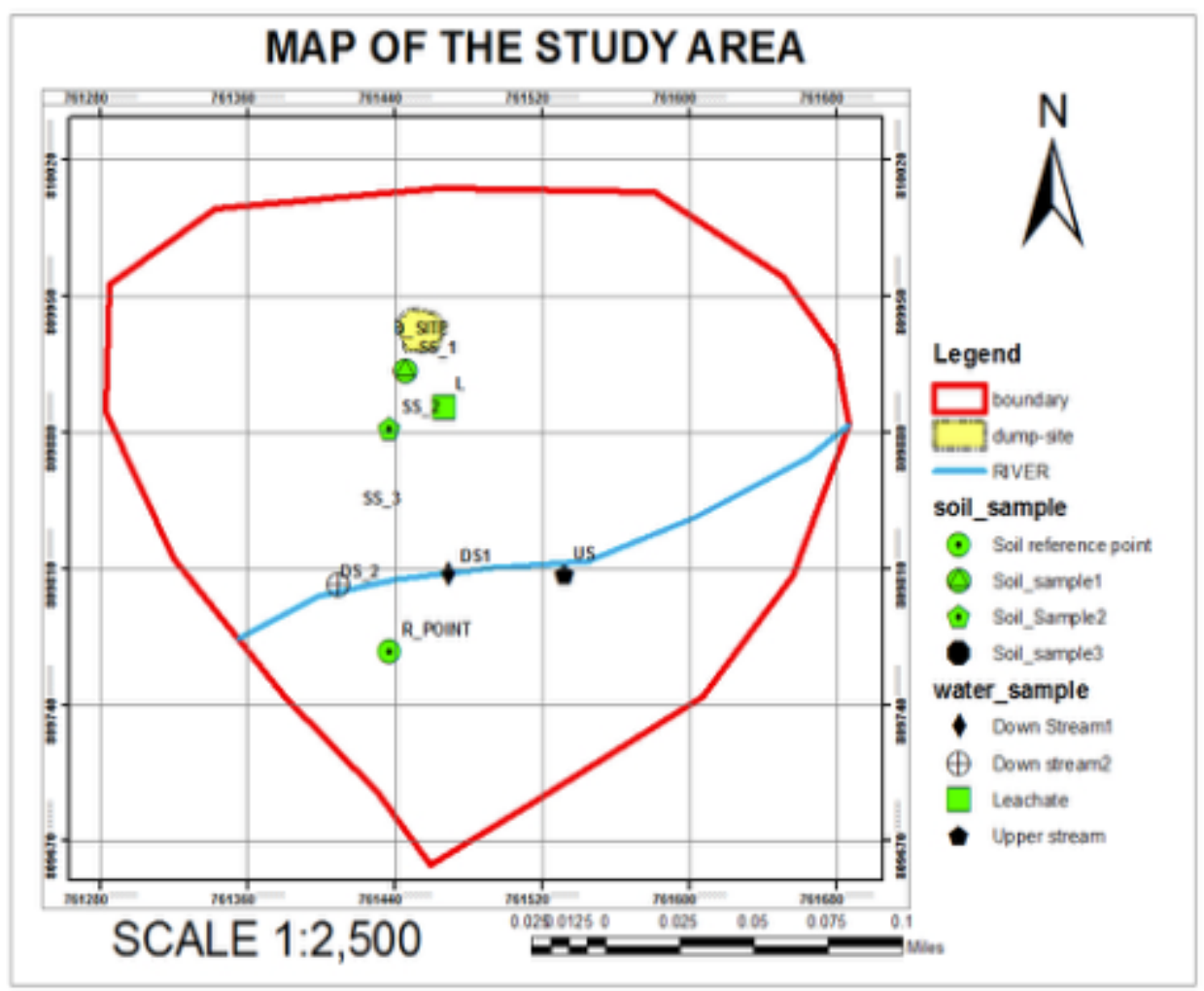

Figure 1

Sampling location for soil and water samples at Teppi town solid waste dump site. 